\title{
A PBL-Based Circulatory System E-Module Based on Research Results to Improve Students' Critical Thinking Skills and Cognitive Learning Outcome
}

\author{
Helsa Rahmatika ${ }^{1}$, Sri Rahayu Lestari ${ }^{*}$, Murni Sapta Sari ${ }^{3}$ \\ ${ }^{1}$ Biology Education Master Program, Malang State University, Malang, Indonesia \\ 2,3 Department of Biology, Malang State University, Malang, Indonesia \\ e-mail: helsarahmatika@gmail.com, srirahayulestari@um.ac.id,murni.sapta.fmipa@um.ac.id
}

\begin{abstract}
The low of students' critical thinking skills and cognitive learning outcomes can be caused by learning difficulties. One of the causes is the lack of availability of learning resources that are relevant and easily applied. The aim of this research is to produce a Problem Based Learning-based e-module based on the results of research that is valid, practical, and effective. The development model used is ADDIE with stages are analyze, design, develop, implement, and evaluate. The resulting e-module is very valid and very practical with the validation value by content expert $=100 \%$, learning expert $=98,65 \%$, field practitioners $=92,85 \%$, and then the value of practicality $=86,99 \%$. The result of quade's rank analysis of covariance test with $p$-value is $0,000<\alpha(\alpha=0.05)$ and the result of ANCOVA test with $p$-value is $0,000<\alpha$. The conclusion is Problem Based Learning-based e-module based on the results of research can improve critical thinking skills and cognitive learning outcomes of students.
\end{abstract}

Keywords: Problem Based Learning, Circulatory, Results.

\section{Introduction}

The $21^{\text {st }}$ century is a globalization and internationalization era (Fong et al., 2014; Osman \& Marimuthu, 2010) and human being will face global competition and problems; thus, it is important for each human being to have the $21^{\text {st }}$ century skills (Pheeraphan, 2013a; Sahin, 2009a). The main skill must be owned by students in the $21^{\text {st }}$ century includes critical thinking (Adi et al., 2017; Thompson, 2011) for it is related to problem solving process (Friedel et al., 2008) occurred in daily life, at work, and all other life aspects (Slameto, 2014). The critical thinking skill is also a foundation for other skills.

Graduate profile of students from biology education's program of Malang State University is expected to be able to master basic biology theoretical concept integrated with the use of logical, critical, systematical, and innovative thinking through IPTEKS (science and technology) approach to analyze various problems in biology field. Achievement of graduate profile of biology education's program of Malang State University (UM) equipped with critical thinking skills could be applied in Human Anatomy and Physiology course. Critical thinking skills have the same achievement elements to the qualification of graduate profile of biology education's program of UM and CPMK of Human Anatomy and Physiology, i.e. it demands students to be able to formulate, analyze, and solve problems (Ristekdikti, 2015).

Learning in Human Anatomy and Physiology course is expected to create students who are capable of mastering concept, solving problems and applying technologies through research-based approaches and have good critical thinking skills, high cognitive learning outcome as well as capable of constructing concept based on facts found in daily life. Facts in field, however, indicate that: learning is still conducted using presentation and discussion $(71 \%)$ and there is no indication of a learning process that trains critical thinking skills and electronic teaching materials are not available; students' critical thinking skill is in moderate level with average of 69.67; students' cognitive learning outcome is in low category with average of 51.67 ; and students experience difficulties in learning (100\%), the reasons include $62.5 \%$ students state that the content is abstract and complex and $22 \%$ state that it is

\footnotetext{
${ }^{*}$ Corresponding author.

Received 20 June 2020; Accepted 18 September 2020; Available online 01 December 2020 (C) 2020 JPI. All Rights Reserved
} 
hard to apply the concept in daily life. One of contents that is hard to understand is circulatory system (22.6\%).

Results of need analysis of students also indicate that learning has not equipped with a more contextual teaching material. Learning sources used mostly refer to sources/references given by lecturer, namely: LKM (student worksheet) (22.6\%), handouts and scientific articles (19.4\%). Learning strategies conducted include discussion-presentation $(71 \%)$ and laboratory practice $(67.7 \%)$. Results of need analysis on lecturers also suggest that teaching materials used in Human Anatomy and Physiology course comprise text book, LKM, and handouts, whereas methods often used are discussion, presentation, and question and answer.

Efforts could be done to cope with the problems include providing teaching materials suitable to technology development and that are capable of improving students' learning interest and make students to be active and think critically. The results of the student needs analysis show that students demand a concise teaching material yet contains important concepts that support content understanding, easy to access, sharpens critical thinking skills, interesting, and presents detail and relevant content. Based on the analysis of student needs, students also want a learning strategy, namely learning based on research results by using electronic teaching materials based on case studies or daily life phenomenon and laboratory practice. It is known previously that students have used printed modules based on research results but not electronic based, therefore students prefer learning strategies based on research results using electronic teaching materials based on case research / everyday life phenomena because according to (Saputro, 2009) e-module is more practical to carry anywhere, is durable, and the e-module can be equipped with audio and video so that students are interested in using it. Another rational reason for the importance of developing an e-module is because usually the time for face-to-face hours during lectures is not optimal, therefore electronic teaching materials are needed to help students' study independently at home in order to understand lecture material. The results of preliminary studies to students on the use of electronic teaching materials are also in accordance with the profiles of graduates of the biology education study program, namely skilled in using software and hardware to analyze and solve biological problems and utilize the latest technology to develop life skills in the XXI century.

Development of module based on research results is one of activities that could expand content applicatively (Primiani, 2018). A module that will trigger an effective learning process could be applied with contextual-based learning to provide current information and improve critical thinking skills (Parmin \& Peniati, 2012). A module that meets the criteria is a PBL-based module. It is supported by results from a preliminary study on students where $51.6 \%$ students choose a problem-based learning using PBL-based teaching materials as a desired learning strategy. The PBL-based module could facilitate students to focus on problem solving (Borhan, 2014; Wong \& Day, 2009) through identification and investigation activities, present a systematic learning experience, and facilitate a constructive and selfdirected learning process (Direktorat Tenaga Kependidikan, 2008).

The PBL-based e-module presents problem as a stimulus based on real events in daily life. The real events are related to research results of single garlic (Allium ssativum) potential on male mice circulatory system that are loaded on the connecting to the problem section of the PBL model syntax. This research was conducted to produce a PBL-based circulation system e-module based on the results of research on the potential of single garlic extract (Allium sativum) on the blood pressure of male mice to improve critical thinking skills and student cognitive learning outcomes that are valid, practical, and effective.

\section{Method}

The PBL-based circulatory system e-module based on research results was developed using ADDIE development model through stages are analyze, design, develop, implement, and evaluate (Branch \& Kopcha, 2014). The ADDIE stages are elaborated in the following section. 
The analyze stage aimed to identify problems that caused gap in learning process. Determination of problems to be studied was conducted by filling questionnaires on learning process by the lecturer of Human Anatomy and Physiology course as well as students who had taken the course. The questionnaires result was compared to the ideal condition of the expected learning and followed by identification of gap occurred. Questions were also given to measure students' initial critical thinking skills and cognitive learning outcome. The critical thinking skills were measured using essay tests in the form of analysis and cases, whereas the cognitive learning outcome was measured using objective tests on circulatory system. The e-module development was conducted to achieve instructional goals, namely compiling a PBL-based circulatory system e-module based on research results of single garlic extract potential and testing the e-module validity, practicality, and effectiveness to students' critical thinking skills and cognitive learning outcome. The targeted audiences included students in fourth semester of biology education study program at Malang State University in academic year of 2019/2020 who were taking Human Anatomy and Physiology course.

The design stage was intended to verify the expected product design and formulate an appropriate testing method. In this stage several activities conducted, namely: task list preparation, performance purpose preparation, and testing strategy preparation by designing and preparing validation sheets, practicality test sheets and effectiveness instruments (pretest and posttest questions to measure students' critical thinking skills and cognitive learning outcome).

The develop stage aimed to develop and validate the e-module. The stage was started with producing content in the e-module including the research results of single garlic (Allium sativum) extract potential on male mice blood pressure. The stage required supporting media in producing the e-module and developed the e-module instruction for use for lecturers and students. The developed e-module would be validated by content expert, learning expert, and field practitioner expert. Next, response questionnaires were given to 15 students who had taken the Human Anatomy and Physiology course. The questionnaire distribution aimed to obtain suggestions, opinions, and comments from the students prior to trial stage. Following the questionnaire distribution, a trial was conducted to 27 offering students from biology education study program of UM of 2018 academic year who were taking the Human Anatomy and Physiology course. The trial was intended to find out the practicality of the developed e-module.

The implement stage was done by using a PBL-based circulatory system e-module based on research results. It was conducted by preparing lecturer to implement lecture using the developed product. Student preparation was also performed by identifying and observing class, arranging implementation schedule, distributing e-module, and preparing other technical matters needed to support the implementation.

The evaluate stage aimed to learn about the e-module weaknesses as a base for improvement. The stage was done in every stage of the ADDIE development. Evaluation was conducted to give assessment on the product quality. It was done by determining evaluation criteria for data obtained from product validity, practicality, and effectiveness tests in improving students' critical thinking skills and cognitive learning outcome. Next, instruments were selected to test the e-module validity, practicality, and effectiveness. The final stage of evaluation was analyzing the evaluation results. The descriptive-qualitative analysis technique used to analyze suggestions, opinions and comments from the validation sheets, student response questionnaires, and learning syntax achievement sheets. The quantitative data analysis used to process quantitative data obtained through data collection instruments on validation questionnaires and practicality instruments in the form of percentage. In addition, parametric difference test and non-parametric test used to test whether or not there was a difference in the mean of dependent variable between two groups by controlling other variables that had influence on the dependent variable.

The research data in the development of PBL-based circulatory system e-module based on research results included qualitative and quantitative data. The qualitative data sources consisted of suggestions, opinions, and comments for improvement from validators and students. The quantitative data sources were in the form of validators' assessment 
questionnaire scores and practicality scores by students as well as results of non-parametric analysis (quade's rank analysis of covariance) and parametric difference test (analysis of covariance). Instruments in the research data collection consisted of need analysis questionnaires, questions to learn about students' initial critical thinking skill and cognitive learning outcome level, expert validation questionnaires, preliminary trial/practicality questionnaires, and pretest and posttest questions to measure students' critical thinking skill and cognitive learning outcome level.

The research data analysis of the development of PBL-based circulatory system emodule based on research results consisted of descriptive-qualitative, quantitative, and parametric difference test and non-parametric test. The qualitative data analysis technique was conducted by grouping information in the form of suggestions, opinions, and comments for improvement from validators and students as a practicality test subject.

The critical thinking skills and cognitive learning outcome were given score based on each assessment rubric and the total score obtained was calculated. The data were then tested for the normality using Kolmogorov-Smirnov and homogeneity using Levine test. If the data were normally distributed and homogeneous, then it followed by analysis of covariance (ANCOVA). If the data were not normally distributed or not homogeneous, however, then the non-parametric difference test was conducted, which was a Quade's rank analysis of covariance.

\section{Results and Discussion Results Analyze}

The analysis result of questions to measure the students' initial critical thinking skill and cognitive learning outcome level indicated that the critical thinking skill was in medium category and the cognitive learning outcome was in low category. It showed the importance of critical thinking skill and cognitive learning outcome improvement efforts for the students in Biology Education's Program of Malang State University in Human Anatomy and Physiology course.

The low students' critical thinking skills and cognitive learning outcome could be connected to difficulties in learning experienced by the students (results of need analysis by students). The difficulties caused by several factors, among others, the content was abstract and complex (62.5\%), it was hard to apply the concept to daily life $(22.6 \%)$, lack of teaching materials that were relevant and easy to apply in daily life $(19,4 \%)$, less effective learning process $(16,1 \%)$, and concept taught was a comprehension in nature $(12,9 \%)$. One of the most difficult concepts to understand was circulatory system (22.6\%). Learning sources used mostly referred to sources/references given by lecturers, which were LKM (student worksheet) (22.6\%), handouts and scientific articles (19.4\%). Learning strategies applied during learning were discussion-presentation (71\%), and laboratory practice (67.7\%). Results of need analysis for lecturer also suggested that teaching materials used in the Human Anatomy and Physiology course were text books, LKM, and handout, whereas methods often used included discussion, presentation, and question and answer.

Based on the need analysis results by the students, they wanted a learning source that is concise but contains important concepts that supports content understanding, easy to access, sharpens critical thinking skills, interesting, and presents detail and relevant content. Learning strategies desired by the students were those that based on research results by using electronic teaching materials based on case studies or daily life phenomenon and laboratory practice. The results of need analysis for lecturer also stated that they never used electronic modules in teaching and learning activities nor developed a research-based teaching material. Therefore, the PBL-based circulatory system e-module based on research results of single garlic extract potential was developed to improve students' critical thinking skills and cognitive learning outcome.

The instructional goal was to compile a PBL-based circulatory system e-module based on research results and to test the e-module validity, practicality, and effectiveness on student critical thinking skills and cognitive learning outcome. The research targeted 
audiences were students in the fourth semester of Biology Education's Program at Malang State University in academic year of 2019/2020 who were taking the Human Anatomy and Physiology course. The product development was conducted in May 2019 - March 2020.

\section{Design}

Result of work plan that had been conducted included syllabus (Rancangan Perkuliahan Semester), lesson design (Satuan Acara Perkuliahan), and test questions on critical thinking skills and cognitive learning outcome along with their rubrics. Result of the testing strategy preparation stage was in the form of instruments to be used to test the validity, practicality, and effectiveness of the developed e-module.

\section{Develop}

In this stage, the development was started by producing the e-module content and research results used as problems in the PBL syntax in each learning activity. The e-module was created using Microsoft Office Word 2013 and Microsoft Office Power Point 2013 in a PDF form and it could be accessed by the students through UM's Sipejar (http://sipejar.um.ac.id/my/). The stage also loaded pictures to support the content, the emodule instruction for use, validation results, results of the students' response and results of the e-module practicality.

The validation results by the content expert were in terms of content feasibility aspect (content and questions on critical thinking skills and cognitive learning outcome), content presentation feasibility aspect, and language feasibility aspect. The three aspects were very valid and could be used in learning. The e-module had several advantages, namely: it could help in understanding circulatory system and its content was easy to understand and could be used as an additional teaching material in teaching and learning process. It could be concluded that the pretest and posttest questions could be used in learning with a little revision.

The validation results by the field practitioner expert suggested that the e-module was very valid according to the aspects of language feasibility, content feasibility, presentation feasibility, and problem-based learning assessment. A conclusion could be drawn that the emodule could be used in learning with revisions. The results of validation by learning experts, namely media (e-module) from the aspects of graphics, presentation, language, and aspects of the e-module have been very valid. The conclusion from the results of media validation is that it can be used in learning with small revisions. The results of validation by field practitioner experts, namely the e-module from the aspects of language feasibility, content feasibility, presentation feasibility, and problem-based learning assessment aspects have been very valid. The conclusion obtained from the results of the validation by field practitioners is that the e-module can be used in learning with revisions.

The results of response questionnaire recapitulation for 15 students suggested that the e-module was very practical based on the aspect of ease of use, learning time effectiveness, and benefit. There were suggestions, opinions, and comments, however, regarding the use of color that would be better if it added with red color so as it would be more contextual (red: blood, arteries and blue: veins) and more interesting instead of only blue color. In addition, picture layout should be considered.

The result of trial conducted on students who were taking the Human Anatomy and Physiology course indicated that the e-module was very practical based on ease of use, learning time effectiveness, and benefit aspects. Suggestions, opinions, and comments from the trial included the MS Word-form file should be given to the students so they could work on their assignment without re-arranging the learning activity column layout that became a mess after converting the pdf-form into word-form and instruction sentences in the learning activity should be clear so the students could understand them. 


\section{Implement}

This stage was conducted by implementing the PBL-based circulatory system emodule based on research results in experimental class. The researcher acted as a lecturer in the circulatory system content in Human Anatomy and Physiology course at the experimental class. In the control class, on the contrary, it was the lecturer of the course himself who conducted the lecture.

Socialization activity was done prior to the implementation so that the students prepared to participate in the learning. The experimental class used syllabus and lesson design that had been validated by the learning expert. The students were provided with emodule through UM's Sipejar prior to face to face meeting in each learning activity. They could read the content, work on the LKM and the formative tests, and watch videos related to problems in the LKM when they accessed the e-module. Learning activity in the control class was done using lecture method, presentation, and discussion by the course lecturer. Meeting was conducted twice for each class. Pretest was done in the first meeting, whereas posttest was in the second meeting in the end of learning.

\section{Evaluate}

The validity value by the content expert in the content feasibility aspect that consisted of 41 assessment items was $100 \%$ with very valid category. In the question content feasibility aspect that comprised 30 assessment items the score was $100 \%$ with very valid category. Likewise, the validity score was $100 \%$ percent with very valid category in the content presentation aspect that consisted of 10 assessment items. In addition, it was also $100 \%$ validity score with very valid category in the language feasibility aspect. The overall validation result from the content expert was $100 \%$ with very valid category. The content expert also validated the pretest and posttest questions with score of $100 \%$ in very valid category.

The learning expert validated media (e-module), the validity score in the graphic aspect that had 10 assessment items was $97.50 \%$ with very valid category; presentation aspect that had 7 assessment items was $100 \%$ with very valid category; language aspect that had 6 assessment items was 100\% with very valid category; e-module aspect that had 14 assessment items was $98.65 \%$ with very valid category. The overall validation result of the media (e-module) was $98.65 \%$ with very valid category; 4) the pretest and posttest questions had validity score of $99.10 \%$ with very valid category.

The validation results by the field practitioner expert indicated validity value in language feasibility aspect that had 7 assessment items of $92.85 \%$ with very valid category; in content feasibility aspect that had 5 assessment items of $90 \%$ with very valid category; in presentation feasibility aspect that had 10 assessment items of $95 \%$ with very valid category; and in problem-based learning aspect that had 6 assessment items of $91.67 \%$ with very valid category. The overall validation result from the field practitioner expert was $92.85 \%$ with very valid category.

The result of response questionnaire recapitulation from 15 students on the three major aspects (ease of use, learning time effectiveness, and benefit aspects) was very practical with practicality score of $88.50 \%$. The result of trial conducted on students who were taking the Human Anatomy and Physiology course on the three major aspects (ease of use, learning time effectiveness, and benefit aspects) was very practical with practicality score of $87.04 \%$.

The results of the students' critical thinking skill evaluation could be elaborated as follows. Mean of the pretest in the control and experimental classes was 46.2 and 37.6, respectively. Mean of the posttest score in both classes was 52 and 76.9 , respectively. It implied that differences between the pretest and posttest scores of both classes were 5.8 and 39.3, respectively. The result of Quade's rank analysis of covariance test for the students' critical thinking skills obtained a $p$-value $=0.000<\alpha(\alpha=0.05)$. It could be inferred that there was a significant difference in the critical thinking skills between the students in the experimental class and those in the control class.

The results of the students' cognitive learning outcome evaluation are described as follows. Mean of the pretest in the control and experimental classes was 56.67 and 62.59 , 
respectively. Mean of the posttest score in both classes was 58.48 and 75.92 , respectively. It implied that differences between the pretest and posttest scores of both classes were 1.81 and 13.33, respectively. The result of analysis of covariance (ANCOVA) obtained a $p$ value $=0.000<\alpha(\alpha=0.05)$. The conclusion is that there was a significant difference in the cognitive learning outcome between the students in the experimental class and those in the control class.

\section{Discussion}

The final result of this development research is a PBL-based circulation system emodule based on the research results of the potential of single garlic extract to improve students' critical thinking skills and cognitive learning outcomes. The e-module is the latest innovation from the print module. (Direktorat Tenaga Kependidikan, 2008) describes the characteristics of the module, namely self-instructional, stand alone, adaptive, and user friendly. Based on the needs analysis questionnaire given to students, students agree that an e-module based on Problem Based Learning (PBL) is developed to improve students' critical thinking skills and cognitive learning outcomes. (Krisanti \& Mulia, 2016) state that PBL can facilitate several skills such as independent learning, interdependent learning, deep learning, assessment, critical thinking, teamwork, time management, and problem solving (Krisanti \& Mulia, 2016). In PBL learning, the problems presented are problems that occur around or in everyday life, therefore the development of a PBL-based circulation system e-module is based on the results of research on the potential of a single garlic extract.

The PBL-based circulation system e-module based on the results of research on the potential of single garlic extract to improve critical thinking skills and student cognitive learning outcomes has been tested for its validity, practicality, and effectiveness so that it can be used in Human Anatomy and Physiology courses. The study of the validation results, practicality, and effectiveness of the e-module that has been developed will be discussed in more detail as follows.

\section{Study on the Validity of PBL-based Circulatory System E-module based on Research Results}

The aspects that were validated by the material expert validator were the feasibility of the content (material and critical thinking skills questions and cognitive learning outcomes), the feasibility of content presentation, and the feasibility of language. (Direktorat Tenaga Kependidikan, 2008) states that products that are suitable for use in learning are valid in terms of the aspects of content feasibility, content presentation, and language feasibility (Direktorat Tenaga Kependidikan, 2008). The validation result by the content expert on the three aspects was very valid and could be used in learning with revision. The advantages of e-module based on the opinion of material experts are that it can help in understanding the circulation system and the contents of the e-module, is easy to understand and can be used as additional teaching material in the teaching and learning process. In accordance with (Permendiknas, 2010) which states that the subject matter in modules must be able to make students learn independently, so that modules are written and presented in such a way as to facilitate student understanding. The developed e-module contains the results of research, so that the problems presented are problems that occur around or in everyday life. Therefore the e-module can help students understand the circulation system.

The media (e-module) validation result was very valid and could be used with a little revision. The e-module that was assessed from its graphic aspect regarding layout, font, color, pictures, and display had a very valid criterion. A good e-module has attractive display with combination of color, picture shape, and clear title (Asyhar, 2011; Direktorat Tenaga Kependidikan, 2008). (Putri et al., 2007) also suggested that a module must present display, design color, font type and size, and language that attract students to read. The e-module aspect includes self-instructional, stand alone, adaptive, and user friendly, including the very valid category. The e-module developed has met the characteristics of self-instructional, which includes clear learning objectives, learning materials are packaged in specific activity units, examples and illustrations that support the clarity of learning material exposure, there 
is an evaluation to measure student understanding, and contains material required. The emodule has met the characteristics of stand alone, that is, it does not depend on other teaching materials/ media, or does not have to be used together with other teaching materials/ media. Although at the visiting and revisiting stage the problem lecturers allow students to search and collect information from various sources. As (Arends, 2012) argues, teachers must assist students in gathering information from various sources, and teachers must ask questions so that students can think about problems and about the types of information needed to arrive at defensible solutions. The e-module developed has met adaptive characteristics, that is, the e-module itself has adapted to developments in science and technology. The e-module can be used anywhere and anytime, if it is connected to the internet or wifi. The e-module is easily accessible, via smartphone or laptop. The e-module has also met the characteristics of user friendly, where every instruction and information on the e-module helps and makes it easier for students to use it. Apart from being equipped with instructions for using the e-module, each learning activity is accompanied by instructions in familiar and communicative language when read by students.

The field practitioner expert validator stated that the e-module was very valid in terms of language feasibility aspect, content feasibility, presentation feasibility as well as problembased learning assessment aspect. In the language feasibility aspect, the e-module had used language suitable to the students' thinking development levels; standardized words; and appropriate spelling, grammar and scientific name writing; however, link between sentences in one paragraph to another should be more coherent. The content feasibility aspect was good as well as the presentation feasibility aspect since the concept was coherent, the e-module component had completed, the evaluation questions were in accordance with the CPMK, and the students had good involvement in the learning. As regards PBL assessment aspect the developed e-module was very good since instruction and assignments presented on the LKM in the e-module was in accordance with the PBL stages.

\section{Study on the Practicality of PBL-based Circulatory System E-module based on Research Results}

The results of response questionnaire recapitulation from 15 students who had taken the Human Anatomy and Physiology course (small group test) indicated a very practical criterion. It showed that the developed e-module was user friendly. It is in line with (Nieveen, 1999) that the developed product must be easily used by anyone. The assessment of emodule practicality by the students in a small group test was intended to provide suggestions, opinions, or comments for the developed e-module improvement. It is consistent with studies by (Lasmiyati \& Harta, 2014) and (Nurjanah et al., 2016) that small group test or readability test aims to evaluate a module product that has been revised according to expert validation. It also aims to obtain data in the form of opinions, critics, and suggestions on the module content and display that uses instrument of questionnaire on students' responses to the module (Rufii, 2015).

Further, trial stage performed to 27 students who were taking the Human Anatomy and Physiology course to learn the developed e-module practicality. In this stage practicality test questionnaire was used with three major assessment aspects, namely: ease of use, learning time effectiveness, and benefit aspects. The results of the students' response questionnaire recapitulation indicated a very practical criterion. It implied that the developed e-module was very practical to use in learning.

\section{Study on the Effectiveness of PBL-based Circulatory System E-module based on Research Results}

Results of data analysis using Quade's rank analysis of covariance suggested that there was a difference in critical thinking skills between the students in the experimental class and those in the control class. Average score obtained by the students in the experimental class was higher than in the control class. It could be inferred that the PBLbased circulatory system e-module based on research results of single clove garlic extract 
potential could improve the students' critical thinking skills. It is in line with several previous studies, among others, students' critical thinking skills experienced an increase through the application of problem solving-oriented e-module (Suarsana \& Mahayukti, 2013) learning using IPA module was proven effective to improve students' inquiry skill and critical thinking skills; module was effective to empower students' critical thinking skills (Nugroho et al., 2017) and module could train students to think critically either directly or indirectly (Naswir \& Johari, 2015)

Results of data analysis using a hypothesis testing of analysis of covariance (ANCOVA) indicated that there was a significant difference in the cognitive learning outcome between the students who learned using PBL-based circulatory system e-module based on research results (experimental class) and those who did not use the e-module (control class). Average score obtained by the students in the experimental class was higher than those in the control class. It could be inferred that the e-module could improve students' cognitive learning outcome. The finding is consistent with (Preeti et al., 2013) and (Winarti et al., 2015) stating that the use of PBL-based module was proven to be able to improve students' cognitive learning outcome.

Learning outcome is a benchmark of student learning success and it conveys to what extent the success of learning system provided (Rohwati, 2012). Cognitive learning outcome is related to students' ability to accept and understand learning content. Learning activity using PBL-based e-module had impact on students' understanding improvement in circulatory content. The application of PBL-model learning could improve students' learning outcome in various studies (Pangestuningsih, 2013; Rahayu et al., 2013).

\section{Conclusion and Recommendation}

The PBL-based circulatory system e-module based on research results was very valid and very practical. The result of the content expert validation was very valid, the learning expert was very valid, the field practitioner expert was very valid, and the e-module practicality was very practical. The e-module could also improve students' critical thinking skills and cognitive learning outcome.

\section{Acknowledgements}

The research was part of PDUPT project under supervision of Sri Rahayu Lestari which was supported by Ministry of Research, Technology and Higher Education, grant No. 1.3.46/UN32.14/LT/2019.

\section{References}

Adi, W. C., Suwono, H., \& Suarsini, E. (2017). Developing Critical Thinking Skills Test for Undergraduate Biology Student. International Conference on Education (ICE2) 2018: Education and Innovation in Science in the Digital Era, 956-966. http://pasca.um.ac.id/conferences/index.php/ice/article/view/127

Akbar, S. (2013). Instrumen Perangkat Pembelajaran. Bandung: PT Remaja Rosdakarya.

Arends, R. (2012). Learning to teach (9th ed). McGraw-Hill.

Asyhar, R. (2011). Kreatif Mengembangkan Media Pembelajaran (Jakarta. Gaung Persada Press.

Borhan, M. T. (2014). Problem based learning (PBL) in teacher education: A review of the effect of PBL on pre-service teachers' knowledge and skills. European Journal of Educational Sciences, 1(1), 76-87. https://eric.ed.gov/?id=EJ1237064

Branch, R. M., \& Kopcha, T. J. (2014). Instructional Design Models. In J. M. Spector, M. D. Merrill, J. Elen, \& M. J. Bishop (Eds.), Handbook of Research on Educational Communications and Technology (pp. 77-87). Springer New York. https://doi.org/10.1007/978-1-4614-3185-5_7 
Direktorat Tenaga Kependidikan. (2008). Penulisan Modul. Departemen Pendidikan Nasional. $\quad$ http://www.academia.edu/download/45070396/26-05-A2-B-PenulisanModul.doc

Fong, L. L., Sidhu, G. K., \& Fook, C. Y. (2014). Exploring 21st century skills among postgraduates in Malaysia. Procedia-Social and Behavioral Sciences, 123, 130-138. https://doi.org/10.1016/j.sbspro.2014.01.1406

Friedel, C., Irani, T., Rudd, R., Gallo, M., Eckhardt, E., \& Ricketts, J. (2008). Overtly Teaching Critical Thinking and Inquiry-Based Learning: A Comparison of Two Undergraduate Biotechnology Classes. Journal of Agricultural Education, 49(1), 72 84. https://doi.org/10.5032/jae.2008.01072

Permendiknas, Pub. L. No. Peraturan Manteri Pendidikan Nasional Nomor 35 Tahun 2010 Tentang Petunjuk Teknis Pelaksanaan Jabatan, Nomor 35 (2010). https://jatim.kemenag.go.id/file/file/peraturantentangPNS/vsef1413864091.pdf

Krisanti, E., \& Mulia, K. (2016). Penerapan Metode Problem Based Learning (PBL) di Kelas Besar di Perguruan Tinggi. PT. Leutika Nouvalitera.

Lasmiyati, L., \& Harta, I. (2014). Pengembangan Modul Pembelajaran untuk Meningkatkan Pemahaman Konsep dan Minat SMP. Pythagoras: Jurnal Pendidikan Matematika, 9(2), 161-174. https://doi.org/10.21831/pg.v9i2.9077

Naswir, M., \& Johari, A. (2015). Pengembangan Modul IPA Terpadu Berorientasi Muatan Lokal untuk Siswa SMP (Laporan) (Laporan Penelitian Kelompok i 042.04.2.400088/2015). Universitas Jambi.

Nieveen, N. (1999). Prototyping to reach product quality. In Design approaches and tools in education and training (pp. 125-135). Springer, Dordrecht; http://www.springer.com/gb/librarians/marc. https://doi.org/10.1007/978-94-011-42557_10

Nugroho, E. S. B., Prayitno, B. A., \& Maridi, M. (2017). Pengembangan Modul Berbasis React pada Materi Jamur untuk Meningkatkan Kemampuan Berpikir Kritis Siswa Kelas X SMA. Didaktika Biologi: Jurnal Penelitian Pendidikan Biologi, 1(1), 1-10. https://doi.org/10.32502/dikbio.v1i1.957

Nurjanah, A. K., Sajidan, S., \& Karyanto, P. (2016). Pengembangan Modul Biologi Berbasis Model Guided Inquiry Laboratory Pada Materi Bioteknologi. INKUIRI: Jurnal Pendidikan IPA, 5(3), 26-39. https://doi.org/10.20961/inkuiri.v5i3.9438

Osman, K., \& Marimuthu, N. (2010). Setting new learning targets for the 21 st century science education in Malaysia. Procedia-Social and Behavioral Sciences, 2(2), 3737-3741. https://doi.org/10.1016/j.sbspro.2010.03.581

Pangestuningsih, D. (2013). Penerapan Model Pembelajaran Berbasis Masalah Sebagai Upaya Meningkatkan Aktivitas Dan Hasil Belajar Siswa Pada Mata Pelajaran IPA Kelas IV SDN Balas Klumprik I/434 Surabaya. Jurnal Penelitian Pendidikan Guru Sekolah Dasar, 1(2), 1-6. https://jurnalmahasiswa.unesa.ac.id/index.php/jurnalpenelitian-pgsd/article/view/2954

Parmin, \& Peniati, E. (2012). Pengembangan modul mata kuliah strategi belajar mengajar IPA berbasis hasil penelitian pembelajaran. Jurnal Pendidikan IPA Indonesia, 1(1), 815. https://doi.org/10.15294/jpii.v1i1.2006

Pheeraphan, N. (2013). Enhancement of the 21st century skills for Thai higher education by integration of ICT in classroom. Procedia-Social and Behavioral Sciences, 103(2013), 365-373. https://doi.org/doi: 10.1016/j.sbspro.2013.10.346

Preeti, B., Ashish, A., \& Shriram, G. (2013). Problem Based Learning (PBL)-An Effective Approach to Improve Learning Outcomes in Medical Teaching. Journal of Clinical and Diagnostic Research: JCDR, 7(12), 2896-2897. https://dx.doi.org/10.7860\%2FJCDR\%2F2013\%2F7339.3787 
Primiani, C. N. (2018). Pengembangan Buku Ajar Berbasis Penelitian Bahan Alam Lokal Sebagai Estrogenik pada Mata Kuliah Fisiologi Hewan. https://doi.org/10.31227/osf.io/9xdfq

Putri, E. H., Sumarmin, R., \& Advinda, L. (2007). Development Module Biology Learning Completely By Conceptual Map For Student Grade Xi Of Senior High School. Development, 163.

Rahayu, I. P., Sudarmin, S., \& Sunarto, W. (2013). Penerapan Model PBL Berbantuan Media Transvisi untuk meningkatkan KPS dan Hasil Belajar. Chemistry in Education, 2(https://journal.unnes.ac.id/sju/index.php/chemined/issue/view/171).

http://journal.unnes.ac.id/sju/index.php/chemined

Ristekdikti. (2015). Paradigma Capaian Pembelajaran. Direktorat Jendral Pembelajaran dan Kemahasiswaan Kementerian Riset, Teknologi, dan Pendidikan Tinggi Republik Indonesia.

Rohwati, M. (2012). Penggunaan Education Game untuk Meningkatkan Hasil Belajar IPA Biologi Konsep Klasifikasi Makhluk Hidup. Jurnal Pendidikan IPA Indonesia, 1(1), 7581. https://doi.org/10.15294/jpii.v1i1.2017

Rufii, R. (2015). Developing module on constructivist learning strategies to promote students' independence and performance. International Journal of Education, 7(1), 18. https://doi.org/10.5296/ije.v7i1.6675

Sahin, M. C. (2009). Instructional design principles for 21st century learning skills. ProcediaSocial and Behavioral Sciences, 1(1), 1464-1468. https://doi.org/10.1016/j.sbspro.2009.01.258

Saputro, A. (2009). Pengembangan Modul Elektronik untuk Mata Kuliah Dasar-Dasar Fotografi [Skripsi Jurusan Kurikulum dan Teknologi Pendidikan]. Universitas Negeri Jakarta.

Slameto. (2014). Developing Critical Thinking Skills through School Teacher Training "Training and Development Personnel" Model and Their Determinants of Success. International Journal of Information and Education Technology, 4(2), 161-166. https://doi.org/10.7763/IJIET.2014.V4.390

Suarsana, I. M., \& Mahayukti, G. A. (2013). Pengembangan E-Modul Berorientasi Pemecahan Masalah untuk Meningkatkan Keterampilan Berpikir Kritis Mahasiswa. JPI (Jurnal Pendidikan Indonesia), 2(2). http://dx.doi.org/10.23887/jpiundiksha.v2i2.2171

Thompson, C. (2011). Critical Thinking Across The Curriculum: Process Over Output. International Journal of Humanities and Social Science, 1(9), 7.

Winarti, Y., Indriyanti, D. R., \& Rahayu, E. S. (2015). Pengembangan Bahan Ajar Ekologi Kurikulum 2013 Bermuatan SETS melalui Penerapan Model Problem Based Learning. Lembaran Klmu Kependidikan, 44(1). http://journal.unnes.ac.id/nju/index.php/LIK

Wong, K. K. H., \& Day, J. R. (2009). A Comparative Study of Problem-Based and LectureBased Learning in Junior Secondary School Science. Research in Science Education, 39(5), 625-642. https://doi.org/10.1007/s11165-008-9096-7 